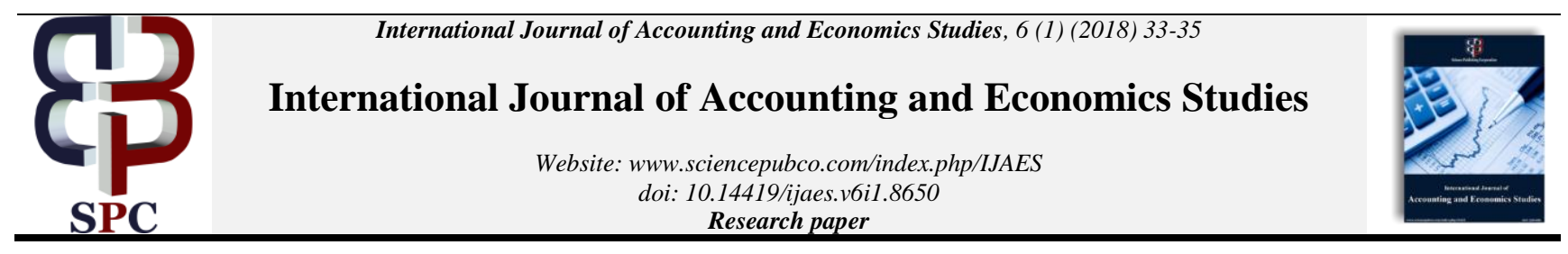

\title{
Financial and non-financial forms of employee motivation - theoretical approach
}

\author{
Dorota Gaudyn * \\ Cracow University of Economics, Rakowicka St, 27, 31-425, Cracow, Poland \\ *Corresponding author E-mail: dorota.gaudyn@onet.pl
}

\begin{abstract}
The article attempts to explain the essence and the growing importance of motivation in modern economic conditions. This subject is still current and evolving, despite the fact that many publications presenting motivational concepts have emerged. Each company should identify the needs of its employees. The article presents the theoretical basis of financial and non-financial forms of employee motivation.
\end{abstract}

Keywords: Management; Motivation; Organization; Salary.

\section{Introduction}

In the present economic reality there are many changes. Competition is increasing, the role of management is increasing, especially knowledge-based, the number of managerial posts increases. Enterprises are exposed to risks that can be mitigated by the skillful use of management knowledge. It must have capital, skillfully manage it, and have the ability to respond to changing environmental conditions. There are various barriers and problems facing the organization. Workers and organizations need to work together to solve them. It is necessary to motivate employees to take initiative and get involved in work. This creates ever-increasing demands for motivational systems. Refinement is a complex process that requires the analysis of existing solutions in order to use an effective system to acquire and retain the best employees and achieve strategic goals. At present, non-economic factors play an increasingly important role in building incentive systems (Kozioł 2002). In the 21 st century, the role of human capital has grown considerably. He decides on a competitive advantage. It is the basis of a knowledge-based economy. Appropriate behavior towards employees affects the level of involvement in work, stimulating creativity.

\section{Essence of motivation}

The aim of the company is to maximize profits. To achieve this goal, managers motivate employees by motivating them. The concept of motivation covers a wide range. It is related to the drivers of human behavior and motivational processes. There are many different definitions because of the complexity of the interpretation of what motivation is. Generally speaking, it is a collection of motives that direct and regulate behavior to meet needs and achieve specific goals (Lipka, Król, Waszczak, Winnicka-Wejs 2010). S. Borkowska (2004) defines motivation as the inner state of a person, defining causes of action, arguing for results. The term motivation is closely linked to the concept of motivation. From the point of view of learning about organization and man- agement, it is one of the management functions. It is defined as stimulating action by applying various stimuli to satisfaction and benefits to the organization (Penc 2000). This means that motivating is a conscious exercise.

Motivation is the driving force behind the behavior of people. In order for it to emerge, it is necessary to be aware of the lack of something, the essence of needs - which means that its unsettling causes distress or disappointment and a chance to meet the need. The motivation of employees depends on how much energy they are willing to spend on achieving their goals (Kopertyńska 2009 p. 13).

\section{Characteristics of selected motivational the- ories}

Theories of motivation were transformed with the study of psychology and human nature. This can be classified as needs, process, reinforcement and cognitive theories. The right choice and use of human resources is crucial for the development of the company. It is necessary to identify factors that identify needs and provide a source of action. Abraham Maslow's theory of needs is one of the most recognizable. It is based on the premise that human needs are arranged hierarchically. They include physiological, security, social, recognition and self-fulfillment needs. According to Maslow, human needs are variable and result from personal growth, which means that with less development, we devote lesser attention to the needs of the higher order for the needs of a higher order. The hierarchy of needs is reflected in the workplace because employees feel the need for security and belonging. Maslow pyramid refers to working conditions. This involves adapting the needs to the relevant factors linked to work and the ability to meet needs. An example of the reference of physiological needs is wages, as a prime motive for taking up a job. Security needs are ensured by ensuring the stability of employment and the right working conditions. The need for recognition can be met by appreciating the effort put into the work by the employee, by giving a bonus or by using word praises. The need for self-fulfillment can be 
realized through professional advancement or personal development.

Frederick Herzberg's concept of needs theory was also presented. This theory consists of two groups: hygiene factors and motivators (satisfaction factors). The focus is not on the needs, but on the factors determining the satisfaction of the work. Hygiene factors are equivalent to physiological needs, security, belonging. With regard to work, they are understood in the financial sense. Include remuneration that is too low for dissatisfaction and, as a result, demotivating factor, working conditions, company policy, working atmosphere, occupational stability, the position of the employee, the degree of control. These factors are not motivating, they only give a sense of lack of dissatisfaction. Satisfaction factors are motivators. To properly motivate the employee to perform work above the minimum must be provided appropriate conditions for development, use the words of appreciation. Herzberg's theory was that high-level work was inextricably linked to employee satisfaction, which is linked to the content of work (Moczydłowska 2009).

D. McClelland's theory is called the theory of three needs. They have needs: achievements, power, affiliation. The need for accomplishment is manifested by the quest for problem solving, the joy of success and the sadness of failure, setting ambitious goals, assuming responsibility for their realization (Bartkowiak 2009). The need for power is evident in people who want to control work, influence the behavior of others. The way in which these people are perceived is extremely important, they value the possibility of competition. The need for belonging is manifested in people for whom interpersonal relations are important, acceptance of the environment. The theory of the three needs pointed to the diversity of employees' professional predispositions and initiated changes in the way employees were recruited through the use of psychological tests.

Douglas McGregor also presented his motivational theory. By analyzing the people's approach to work and challenging, he created two opposing theories: $\mathrm{X}$ and $\mathrm{Y}$. Theory $\mathrm{X}$ refers to employees who negatively relate to their duties, avoid work. Under the assumptions of theory $\mathrm{X}$ also the employer does not attach attention to the development and training of employees. Motivating employees is at the level of physiological and security needs. It means that the employee should be controlled, apply the punishment system, direct it, because employees do not want to take responsibility. In contrast, theory Y is the opposite of theory X. It assumes that employees have a positive attitude to work, are not afraid to take up challenges, take responsibility, work is a factor of human development, motivates for self-realization. Managers after the analysis and observation of the employees, accepting the submission of each theory must take into account its effects. Applying theory $\mathrm{X}$ will affect employees in such a way that they adopt the attitude of the minimum necessary to receive a pay. On the other hand, assuming the assumptions of $\mathrm{Y}$ theory, it encourages employees to engage in tasks (Koźmiński 2009).

\section{Concepts of the motivational system}

It is in vain to seek a clear way of defining what a motivational system is. There are various shots presented depending on the author. L. Kozioł states that the motivational system is a set of motivational factors and tools that constitute the whole, creating conditions for functional organizational behavior towards the company (Kozioł 2002). The purpose of creating incentive systems is the success of the enterprise, the achievement of market development and the success of employees. When preparing the incentive system, the objectives and conditions of the company should be taken into account. It is not enough to integrate employees' goals with company goals. It is necessary to stimulate or create creative potential in the employees (Juchnowicz 2000 p. 211). There are three types of measures that affect employee motivation: coercive measures, incentives, and persuasion. The most effective of these are the means of persuasion, because they refer to internal motivation. Motivation is influenced by external and internal factors. External factors from the company's environment include legal issues, socio-economic, political and labor market situation (Moczydłowska 2008).

\section{Factors of financial motivation}

There is a large number of concepts in the literature that define the issue of remuneration. According to the Labor Code, remuneration is the total amount of cash and benefits in kind that are paid to employees for employment in an economic entity and calculated according to the principles of wage and employment statistics. Remuneration consists of mandatory and additional components. The pay is the price or income you receive for work. The price of labor varies depending on the labor market, demand and labor supply. Pay is a key motivator. Properly used stimulates the behavior of employees in the company. It will be important as long as society is poor. In economically developed countries where workers are remunerated, the importance of pay as a motivator decreases in favor of other motivating factors (Oleksyn 2009 p. 149). Money in the form of pay attracts the best specialists to the company, often decides to stay employees in the organization. This does not mean, however, that the higher the pay, the greater the motivation. The complexity of the influence of the factors is due to the extended function of money which is realized in the consciousness of people. Money is the source of income, it is an element of stimulating the employee to work, it is a determinant of the standard of living, achievements, qualifications. Five basic functions pay off. They can be analyzed from the point of view of the employer or employee.

Income function is understood as income earned by employees, who are often the only source of income. They are a means of acquiring goods, covering the cost of living, the development of the worker. It is important that the remuneration is at an appropriate level. Otherwise, it may lead to a decrease in labor productivity, the search for additional sources of income, which can result in fatigue, worsening of employee relationships and extreme poverty and poverty. Considering the issue of remuneration, the question of minimum remuneration, which is based on remuneration protection, is often discussed. The cost function means that salaries are a cost to an enterprise, which includes: basic salary, insurance premiums, funds such as the Labor Fund, the Guaranteed Employee Benefits Fund, the Social Benefits Fund, the costs of recruiting employees, taking on employment and redundancies. It is important to rationalize costs and get the highest rate of return on inputs to employees. Motivation is realized by integrating payroll expectations with the company's payroll capabilities. The premise of this feature is the ability to get higher incomes as a result of more efficient work. The employer pays the employee for a greater involvement in the work, favoring the interests of the enterprise (Pocztowski 1998).

The social function is based on the notion that job evaluation must correspond to value systems in a given country, social norms. Adherence to this premise helps prevent conflicts of pay, their unreasonable span, employee exploitation, unfair competition.

Market function means that the amount of pay is in the labor market. The amount of remuneration reflects many components, including the employee's education, experience and skills. The average wage also depends on the geographical location of the market. Based on this criterion, higher wages are received by employees in higher-income regions than by analogous workers in the less developed localities.

In addition to the fixed portion of the basic salary, there is also variable remuneration, which applies in the form of bonuses (individual, team, general, long-term), awards or incentives for producers and sellers. These are the pay components that effectively affect an employee. They allow the company to motivate employees to work effectively, rewarding for specific accomplishments and goals. This solution is beneficial for the employer because of the association of results with the incentive system. It also pro- 
vides a number of other benefits: it allows you to assess your human resources, identifies employees with the company, contributes to the development of the organization, gives you the ability to estimate the effectiveness of each motivation. (Gick, Tarczyńska 1999). The definition of the basis for setting premiums, evaluation criteria plays a key role. Also its height should be appropriate for the type of work and at the same time taking into account the degree of influence of the employee on the efficiency of the work performed. Bonus incentives refer to pay functions. From the point of view of income function, it is possible to increase the employee's income in relation to more efficient work. The motivational function of salaries is accomplished by achieving the results and achieving the goals set by the company. From the perspective of the employer, the premium represents the cost function.

\section{Factors of non-financial motivation}

Limited salary motivations force employers to look for nonfinancial incentives for employees. These stimuli are complementary to each other. Material factors affect faster, but non-material ones work slowly but permanently. Proper selection of motivation tools is about the success of the company, so managers should analyze the situation of the company and employees in order to select the most effective motivation system (Zbiegień-Maciąg 2006 p. 122-123). Non-financial incentive tools are divided into material and non-material ones.

Forms of non-payment financial motivation can take the form of social benefits and show the care of the employer towards the employee. They appear as:

- benefits in kind (this is an additional component of remuneration provided to employees in a form other than cash, but only if they provide for statutory labour law),

- material attributes of the position (getting a business car, laptop, phone, rich office equipment, access to kitchen or answering machine),

- check-in for dismissed employees (although it is paid in a cash-based manner, it is classified as non-pay incentive because it is a promise of payment at the end of the employment relationship)

- retirement and pension schemes (those that are collected as deferred income),

- $\quad$ stock options, shares and bonds (this is a way of postponing the payment, which consists in the possibility of resale of securities),

- social welfare benefits (these funds are used to finance holiday rentals, grants, loans),

- cafeteria systems (include the fixed part of the salary paid in cash and in kind, which are the benefits provided by the employer such as private medical care, lunch vouchers, pool passes, gym, cinema tickets - Adamik, Nowicki 2012 p. 360-392)

The second group are motivational factors of non-financial nonmaterial, including:

- appreciation of the employee and approval of his work

- friendly atmosphere, efficient cooperation and communication,

- a precisely defined career path and the ability to develop and improve,

- ensuring stable working conditions and employment (Forsyth 2001).

An important issue to be addressed when discussing the topic of remuneration and motivation for work is a fair wage. Since 1997 research on the theories of measuring human capital has been started in Poland, initiated by M. Dobija. They depict the relationship between human capital and fair pay. The basis of the theory of fair wage is the understanding that capital is the ability to do work. The human labor capital model presented by J. Renkas covers the costs of living, education, time, economic constant, age and number of years of education (2016 p. 284-301).

\section{Conclusion}

Motivation is an important issue in the process of managing human capital. Identifying motivational factors plays a key role in creating an effective incentive system in an enterprise. Remuneration factors continue to be important, but the issues of nonfinancial is becoming more important.

\section{References}

[1] Adamik A., Nowicki M. (2012), Metody i narzędzia motywowania personelu. [w:] Podstawy zarzadzania. (red.) ZakrzewskaBielawska A., Warszawa: Oficyna Wolters Kluwer, Warszawa, s. 360-392.

[2] Bartkowiak G. (2006), Psychologia zarządzania. Poznań: Wydawnictwo Uniwersytetu Ekonomicznego w Poznaniu, s. 126.

[3] Borkowska S. (2004), Motywować skutecznie. Warszawa: IPiSS.

[4] Forsyth P. (2001), Jak motywować ludzi. Gliwice: Heloin, s. 64.

[5] Gick A., Tarczyńska M. (1999), Motywowanie pracowników: systemy, techniki, praktyka. Warszawa: Polskie Wydawnictwo Ekonomiczne, s.234.

[6] Juchnowicz M. (2000), Motywowanie w toku pracy: Zasoby ludzkie $w$ firmie. Organizacja kierowanie, ekonomika. pod. red. Sajkiewicz A., Warszawa: Poltext, s. 211.

[7] Kodeks Pracy. art. 77 -93 (tekst jednolity) (Dz.U.1998.21.94).

[8] Kodeks Pracy. (tekst jednolity) (Dz. U. z 2.06.1996, nr 24, poz. 110).

[9] Kopertyńska M. W. (2009), Motywowanie pracowników. Teoria i praktyka. Warszawa: Agencja Wydawnicza Placet.

[10] Kozioł L. (2002), Motywacja w pracy. Determinanty ekonomicznoorganizacyjne. Warszawa-Kraków: PWN.

[11] Koźmiński A. K. (2002), Zarzadzanie teoria i praktyka. Warszawa: PWN, s. 56.

[12] Lipka A., Król M., Waszczak S., Winnicka-Wejs A. (2010), Ksztaltowanie motywacji wewnętrznej. Koszty jakości $i$ ryzyko. Warszawa: Difin, s.7.

[13] Moczydłowska J. M. (2008), Zarządzanie kompetencjami zawodowymi a motywowanie pracowników. Warszawa: Difin.

[14] Oleksyn T. (2006), Wynagradzanie efektywne - przeglad problemów. w: Zarządzanie zasobami ludzkimi. Teraźniejszość $i$ przyszłość. red. Borkowska S., Warszawa: IPiSS, s. 149.

[15] Penc J. (2000), Kreatywne kierowanie : organizacja i kierownik jutra, rozwiąywanie problemów kadrowych. Warszawa: Agencja Wydawnicza Placet.

[16] Pocztowski A. (1998), Zarządzanie zasobami ludzkimi. Zarys problematyki i metod. Kraków: Oficyna Wydawnicza Antykwa, s. 143.

[17] Renkas J., (2016), Ekonomia pracy. Teoria godziwych wynagrodzeń, Prace Naukowe Uniwersytetu Ekonomicznego we Wrocławiu, nr 439, s. 284-301.

[18] Zbiegień-Maciąg L. (2006), Nowe tendencje $i$ wyzwania $w$ zarządzaniu personelem. Kraków: Oficyna Ekonomiczna Grupa Wolters Kluwer, s. 122-123. 